\title{
CONCEPTUALIZATION IN THE ENGLISH GERUND AND ITS SPANISH EQUIVALENTS: A CONTRASTIVE COGNITIVE STUDY
}

\author{
M. ${ }^{a}$ Ángeles Gómez CASTejón \\ Catholic University of Leuven (K.U.Leuven, Belgium) \\ angeles.gomezcastejon@hotmail.com
}

\section{Abstract}

The English gerund and its Spanish equivalents show different levels of conceptualization when carrying out a contrastive study. In particular, we will focus on the conceptualization of the Spanish equivalents which correspond to the English construction [physical perception verb + Noun Phrase + -ing form]. There are certain difficulties in relation to our study. Firstly, the traditional characterization of the English gerund, based on tense and aspect criteria, proves to be inadequate to establish its meaning. Secondly, the -ing form with physical perception verbs has been interpreted as a participle. In this paper, we will propose that the -ing form with physical perception verbs can also have a gerundial reading. In addition, we will argue that the cognitive approach provides a valid characterization of the English gerund which constitutes, in turn, the base for the contrastive cognitive study. Regarding the contrastive study, the Spanish equivalents exploit, in general, the eventive reading of the English gerund.

KEY WORDS: English gerund; Spanish equivalents; levels of conceptualization; contrastive cognitive study; gerundial reading; eventive reading

\section{RESUMEN}

El gerundio inglés y sus equivalentes españoles muestran diferentes niveles de conceptualización al llevar a cabo un estudio contrastivo. En particular, nos 
centramos en la conceptualización de los equivalentes españoles que corresponden a la construcción inglesa [verbos de percepción física + frase nominal+ forma en -ing]. Hay ciertas dificultades relacionadas con nuestro estudio. En primer lugar, la caracterización tradicional del gerundio inglés, basada en criterios temporales y aspectuales, no resulta adecuada para establecer su significado. En segundo lugar, la forma en -ing con verbos de percepción física se ha interpretado como participio. En este artículo, proponemos que la forma en -ing con verbos de percepción física puede tener también una lectura gerundiva. Además, sostenemos que el enfoque cognitivo proporciona una caracterización válida del gerundio inglés que constituye, a su vez, la base para el estudio contrastivo cognitivo. En cuanto al estudio contrastivo, los equivalentes españoles explotan, en general, la lectura eventiva del gerundio inglés.

PALABRAS ClAVE: gerundio inglés; equivalentes españoles; niveles de conceptualización; estudio contrastivo cognitivo; lectura gerundiva; lectura eventiva

\section{INTRODUCTION}

Previous contrastive studies between the English gerund and its Spanish equivalents display serious limitations in their analysis of these constructions.

Although the subject of the English gerund and its Spanish equivalents has been studied from several perspectives, there are few relevant studies so far. Studies exist (Álvarez, 1991; Fente, 1971; Criado de Val, 1972; Losada, 1980; Querada, 1972) which consider the -ing a unique form with two functional variants, the gerund and participle categories that must be analyzed separately. However, we detect a common problem to all these studies: they lack an exhaustive linguistic analysis. For example, most of these studies only provide a list of equivalents with their respective examples.

There are more recent studies than those cited in the previous paragraph. In particular, we highlight the studies of Piñeiro and Garcia (2001), Alonso García (2003) and Izquierdo (2006 and 2008). Their research shares a functional descriptive approach. These studies provide, in general, a rigorous linguistic description, but some of them, in particular the work of Izquierdo (2006 and 2008), approach the analysis of the -ing form in a comprehensive manner: all -ing forms belong to a single category and therefore there is no need to make a distinction between the terms «gerund» and «participle» (Huddleston \& Pullum, 2002: 1222). All the works mentioned above share a functional descriptive approach with a direct application in translation when it comes to translation.

Based on the previous observations, on the one hand, we corroborate that the -ing form has been analyzed in different ways. On the other hand, we note that previous studies are limited in scope: some of these studies lack an exhaustive linguistic analysis whereas others provide a functional descriptive approach exclusively applied to the field of translation. In this context we believe there is a gap in the previous contrastive studies that a cognitive approach could fill as explained in the following paragraphs.

In our contrastive study the starting point is the English gerund. There are two areas of difficulty when analyzing the English gerund. Firstly, based on the bibliog- 
raphy used, it can be ascertained that the characterization of the English gerund is one of the main difficulties. Traditionally, the characterization of the English gerund has been established in terms of tense/aspect criteria, but its meaning and nature have not been coherently established as shown in the following paragraph. Secondly, there are specific -ing forms that are difficult to classify as gerunds or as participles: the so-called half-gerunds, according to the terminology of Sweet (1968) and Duffley (2006) (e.g. the sequence [physical perception verb + Noun Phrase (NP) + -ing form]).

In the first place, the characterization of the English gerund based on tense and aspect criteria (i.e. simultaneity/imperfectivity respectively) is not valid because the English gerund not only expresses all temporal possibilities (i.e. simultaneity, anteriority and posteriority in (1a), (1b) and (1c), but we have also found cases where the temporal relation is not pertinent, as in (1d). Besides, the English gerund can express both imperfective and perfective readings, as in (1e):

(1) a. I hate cooking. I guess I should learn ${ }^{1}$. (DISG 347)

b. I cannot honestly recollect ever enjoying that. I've searched my heart, but it's hard to say, now, isn't it? (LILIE 246)

c. If there's such a thing as reincarnation, I wouldn't mind coming back as a squirrel. They must have knee-joints like tempered steel. (THE 769)

d. Does an artist's life entail sleeping with anyone and everyone? (YOU 30)

e. Just thinking about those years, Thelma having an affair with Harry almost right up to when she died. (RAB 306)

${ }^{1}$ All examples provided can be found in my corpus. In all examples the source texts are provided in brackets after the example. A specific code has been used in which the first letters make reference to the title of the source text and the numbers refer to the order within the corpus. The title of the source texts and their specific codes are the following:

\begin{tabular}{|c|c|c|}
\hline Author & English Original Text & Spanish Translation \\
\hline D. Lodge & $\begin{array}{l}\text { Thinks }(=\mathrm{THIN}) \\
\text { Therapy }(=\mathrm{THE})\end{array}$ & $\begin{array}{l}\text { Pensamientos secretos (=PENSA) } \\
\text { Terapia (= TERA) }\end{array}$ \\
\hline D. Lessing & $\begin{array}{l}\text { Love, again }(=\mathrm{LOVE}) \\
\text { The sweetest dream }(=\mathrm{SWEE})\end{array}$ & $\begin{array}{l}\text { De nuevo, el amor (= AMOR) } \\
\text { El sueño más dulce (= SUEDUL) }\end{array}$ \\
\hline N. Gordimer & $\begin{array}{l}\text { None to accompany me } \\
\text { (=NONE) } \\
\text { The pickup (=PICK) }\end{array}$ & $\begin{array}{l}\text { Nadie que me acompañe }(=\mathrm{NADIE}) \\
\text { El encuentro }(=\mathrm{ENCUEN})\end{array}$ \\
\hline J. M. Coetzee & $\begin{array}{l}\text { Youth (=YOU) } \\
\text { Disgrace (=DISG) }\end{array}$ & $\begin{array}{l}\text { Juventud (= JUVEN) } \\
\text { Desgracia (= DESG) }\end{array}$ \\
\hline J. Updike & $\begin{array}{l}\text { In the beauty of the lilies } \\
\text { (= LILIE) } \\
\text { Licks of love (=RAB) }\end{array}$ & $\begin{array}{l}\text { La belleza de los lirios (= LILIE) } \\
\text { Conejo en el recuerdo y otras historias (= BELI) }\end{array}$ \\
\hline P. Roth & $\begin{array}{l}\text { Sabbath's theater (=SAB) } \\
\text { The human stain (=HUM) }\end{array}$ & $\begin{array}{l}\text { El teatro de Sabbath }(=\text { TEASAB }) \\
\text { La mancha humana }(=\mathrm{MANHU})\end{array}$ \\
\hline
\end{tabular}


From our point of view, the difficulty in the characterization of the -ing form could be counteracted by adopting a cognitive approach. The cognitive analysis makes it possible to establish a valid and coherent characterization of the English gerund (Langacker, 2008, 2000; Declerck, 2006; Verspoor, 1996) as explained in section 3.1. and constitutes the basis for the contrastive study. Moreover, the cognitive characterization of the English gerund enables us to determine the different levels of conceptualization between the English gerund and its Spanish equivalents.

Secondly, in our opinion, the -ing form classification constitutes one of the most representative cases in the English language where a non-discrete approach is required. The traditional binary difference between gerund and participle is not always clear, as there are forms sharing certain properties of the «gerund» prototype and others of the «participle» prototype. In particular, physical perception verbs can appear followed by a Noun Phrase (NP) plus an -ing form. This construction ( $N P+$-ing form») has been generally interpreted as two separate constituents (Kortmann 1995; Quirk 1985; Dirven 1989 and Langacker 1991 and others) and this implies that the -ing form functions as a participle. Nevertheless, we claim that there is an alternative interpretation: the «NP + -ing form» can be interpreted as a single constituent (Borgonovo, 1996) and this involves an -ing form functioning as a gerund. We support this hypothesis based on the cognitive resemblance of physical and cognitive verbs. Traditionally, the -ing form combined with cognitive perception verbs has been interpreted as a gerund. Due to their cognitive resemblance, we argue that the -ing form with physical and cognitive verbs must have the same interpretations (gerundial and participial interpretation) as explained in section 3.2.

Taking into account all previous observations, we claim that the extra possibility of a gerundial reading for the -ing form in the sequence [physical perception verb $+\mathrm{NP}+$ English gerund] in our corpus, as well as the great variety of translations this construction «triggers», justify its inclusion in this paper.

Finally, according to the corpus data, we have confirmed that the English gerund offers a great variety of translational options and this variety must be interpreted as a reflection of a different cognitive organization. In other words, the target and source language propose different structures and construals to encode the same situation (Verhaert, 2006: 314). In this context, it is important to determine the criteria that govern the process of equivalence between them. The notion of equivalence is dynamic, and this dynamism implies a scale on which there are various degrees of equivalence or correspondence (Izquierdo, 2008: 348). In this regard, we claim that the cognitive characterization of the English gerund constitutes the basis of the contrastive cognitive study.

The purpose of this paper is to analyze the conceptualization of the Spanish equivalents in relation to the English gerund from a cognitive point of view ${ }^{2}$. Particular attention will be paid to the conceptualization of the Spanish equivalents which correspond to the English construction we are concerned with (i.e. [physical perception verb + NP + English gerund]).

2 This particular approach has also been adopted in our article entitled «Different levels of conceptualization of the English gerund and its Spanish equivalents» published in AELFE2011 proceedings. 
The structure of this paper is as follows. In section 2, we will outline the methodology and empirical base. In section 3, we will provide the cognitive characterization of the English gerund and present the status of the -ing form combined with perception verbs. And, finally, in section 4, we will analyze the conceptualization of the Spanish equivalents in terms of their cognitive resemblance to the English gerund.

\section{Methodology And empirical Base}

For this study we have adopted a cognitive approach (in particular, Langacker as the leading exponent). We believe that this approach solves some of the limitations exposed in section (1) to a great extent. On the one hand, the cognitive analysis makes it possible to establish the meaning of the -ing gerund in a coherent way as an abstract entity with an eventive reading (Langacker, 2008, 2000; Declerck, 2006; Verspoor, 1996). On the other, this analysis enables us, in turn, to provide an explanation of the equivalence between the English gerund and its Spanish equivalents based on their cognitive resemblance.

This cognitive approach has been completed with the most relevant studies devoted to the Spanish equivalents. In particular, we have taken into account works that focus on the configuration of the Spanish equivalent included in this study. In this context, we have included the works of Fernández Lagunilla (1999, 2003), Hernanz (1999), Gómez Torrego (1999), Delbecque \& Lamiroy (1999), Brucart (1999), Bosque (1999), Rodríguez Espiñeira (2000), López García (2005); and the PhD dissertation of Izquierdo Fernández (2008), Verhaert (2006), Hanegreefs (2008), to mention some.

The inclusion of the studies mentioned above is justified by the limitations found in previous contrastive studies between the English gerund and its Spanish equivalents. Regarding the translation of the -ing form, there are recent studies, such as, the studies of Piñeiro \& García (2001), Alonso García (2003) and Izquierdo (2006; 2008). All these works share a functional descriptive approach. For example, the study of Alonso Garcia (2003) describes the errors of equivalence between the Spanish equivalents and the -ing form, while the studies of Pineiro \& Garcia (2001) and Izquierdo (2006 2008) share the same descriptive approach as the previous one (i.e. Alonso García, 2003) but with a direct application to translation. For example, the work of Izquierdo (2006; 2008) is focused on the functionality of constructions with -ing and how these constructions are translated into the target language (i.e. Spanish). Although these studies provide a rigorous linguistic description, we claim that they show a limitation, because they don't include a conceptual description of the English gerund and its equivalents. As we have seen, this conceptual description allows us to establish a hierarchy between the English gerund and its equivalents.

At this point, it seems appropriate to present the empirical basis used for our study. For the purpose of this study, we have compiled a parallel corpus. When contrasting linguistic phenomena which are believed to be equivalent, parallel corpora seem to be an appropriate methodology for contrastive analysis, because they 
provide substantial amounts of language usage in a communicative context. Moreover, the use of parallel corpora is relevant in contrastive linguistics for two main reasons: in the first place, they provide new insights into the languages compared; aspects that are likely to go unnoticed in monolingual corpora (Johansson, 1998: 4); and, secondly, because a parallel corpus can reveal/evidence particular relations of sense as well as of form, which would be very difficult to capture without such data (Mauranen, 2002: 161).

Our corpus is an English-Spanish parallel corpus and includes approximately 1000 occurrences of English original texts and their Spanish translations respectively. The works are defined according to the usual parameters such as author, genre and the year of publication according to Delbecque's observations (1987: 67). In this regard, the corpus is homogeneous in terms of gender (i.e. contemporary narrative fiction) and date of publication (i.e. from 1994 to 2002). The corpus includes 12 original texts of six authors (two per author) and their Spanish translations. This variety of works (two works per author, twelve pieces in total) ensure, on the one hand, that our analysis is not limited to a specific idiolect of English and, on the other hand, that there is an interesting range of language option possibilities, which is consistent with the nature of the English gerund as a form with a multi-variety of functions (Izquierdo, 2008).

\section{Pre-analysis: Characterization AND Status of THE ENGLish Gerund}

Previous to the analysis and discussion of the data (4), we will present the cognitive characterization of the English gerund (3.1.) and then we will focus on the status of the -ing form combined with physical perception verbs (3.2.).

\subsection{Characterization of the English gerund: an «integrating» element}

We have already proven that the characterization of the English gerund cannot be established in terms of tense and aspect and therefore we proceed to provide its meaning from a cognitive approach. This approach provides a characterization of the English gerund which is valid for all the contexts this category appears in. This justifies its integrating character. In this regard, the progressive -ing form and the nominalization process are relevant factors to be taken into account.

From a cognitive approach, the progressive-ing form does three things to the verb stem. Firstly, the progressive-ing form construes a process holistically, thus making the profiled relationship non-processual and therefore the English gerund has summary scanning. Secondly, the -ing form takes an internal perspective of the action; technically, this means that the -ing form imposes an immediate temporal scope of predication, consisting of some internal portion of the overall relationship, and it selects this internal portion «for focussed viewing». This temporal immediate scope imposed by the progressive -ing form limits the portion of the event observed. Hence, it can be inferred that the conceptualizer (speaker/observer represented by $\mathrm{C}$ ) conceptualizes an 
event seen from a close perspective (Verspoor, 1996: 437-438), as shown in the figure below:

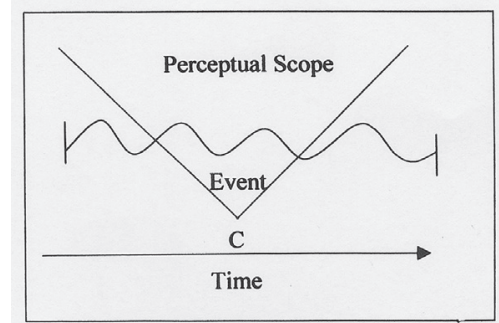

Figure (1): The close perspective of the -ing form (Verspoor, 1996: 438)

The profiled relationship selected «for focussed viewing» is construed as homogeneous due to its qualitative uniformity. In other words, while the component states, which make up the internal portion of the overall relationship, may be different, they «all qualify as representative internal states of the same base process» (Langacker, 2008: 155-156).

With regard to nominalization, this process reflects a higher level of conceptual organization (Langacker, 2008: 106). In Fig (2), the English gerund, depicted in (2c) with a circle, undergoes the furthest step of nominalization. All the component states are profiled collectively and included in the abstract region or thing it profiles construed as mass-like and homogeneous (Langacker, 2008: 120-121):
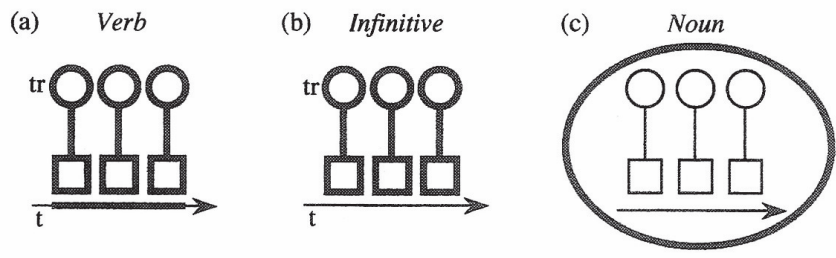

Figure (2): Nominalization (Langacker, 2008: 119)

Based on all previous cognitive observations, we argue that the English gerund is an event seen as a whole from a close perspective of the conceptualizer. When an event or process is construed as a whole, this implies, on the one hand, that the event is conceptualized as an abstract entity (Langacker, 2000: 86) and, on the other, that the event profiled has no temporal internal structure (i.e. beginning, middle and end) (Declerck, 2006: 99).

\subsection{Status of the -ing form with perception verbs: a «problematic» issue}

The status of the -ing form with perception verbs is one representative case of the so-called half-gerund cases. In perception literature, it is generally accepted that the -ing 
form is interpreted as having a participial and a gerundial interpretation with physical and cognitive perception verbs respectively. Nevertheless, due to the «cognitive resemblance» of these verbs, we state that the -ing form combined with these verbs must have the same interpretations (participial/gerundial).

Physical and cognitive perception verbs belong to the same semantic group according to Givón's classification (1993: 133): «Perception-cognition-utterance (PCU) verbs». The semantic characterization of PCU verbs may be given in the following terms: the subject of these verbs is a conscious human agent who «perceives or cognizes a state or event» (1993: 133). This perception or cognition is then coded in the complement clause. Consequently, the complement clause functions as the object of the mental activity depicted by the main verb (Givón, 1993: 133).

The coincidence between physical and cognitive perception verbs is evident from their definitions. In particular, the term «cognitive perception verb» is limited to verbs having a mental picture of the event depicted by the complement clause and implies «[...] the conceptualiser's ability to form pictures in her/ his mind about what something could be like, something which is not actually before the eye or within experience» (Hamawand, 2002: 208). With these verbs, the action denoted by the English gerund does not require to be actually done but it requires that the conceptualiser sees or interprets the action as real (Wierzbicka, 1988:71). This particular observation highlights the idea of the semantic proximity of these two types of verbs (i.e. physical and cognitive verbs).

In addition, there are some relevant cognitive processes that physical and cognitive perception verbs have in common. Firstly, in perception, the main subject is an observer or an experiencer rather than an agent and the main verb establishes a perceptual relationship between its subject and the complement clause. The observer directs his/her attention to the stimulus and then the stimulus causes him to enter into a particular mental state (Croft, 1993: 64); in fact, it is a two-way causal relation:

Direct attention to

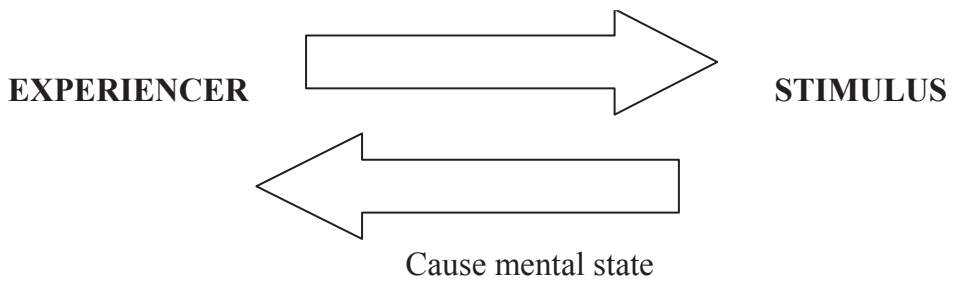

Figure (3): The two-way causation in perception (adopted from Croft's schema (1993: 64))

From our point of view, the observer or the experiencer shows perceptual commitment. The term «perceptual commitment», created for the purpose of this analysis, should be considered a principle governing the verbs of physical and cognitive perception. It implies willingness on behalf of the observer with respect to the physical and cognitive perception of the content denoted by the complement clause. 
The second cognitive process that physical and cognitive verbs shares, has to do with the way perceptual apprehension takes place. Both in physical and cognitive apprehension, the -ing form symbolizes a directly and immediately perceived event. The conceptualizer (speaker/viewer) construes the event as seen from a very close-by perspective; to put it another way, «he views the event on stage» (Verspoor, 1996: 439).

Based on all previous observations, we argue that there are two main issues in the description of the «participial» and the «gerundial» interpretation of the -ing form: 1) the role of the main clause subject; and 2) the conceptualization of the event ${ }^{3}$.

With regard to the «participial interpretation», the main clause subject is not fully responsible for the event denoted by the complement clause: the complement clause subject can suspend or stop the event or decide to «leave» the viewing frame (this is represented by a vertical dashed arrow). As far as the conceptualization of the event is concerned, it is evoked as something incomplete: it implies a partial view as something captured at any given point between its beginning and its end (this is highlighted by the presence of a bold straight line and a wavy line: the distinction between the «perceived» and «non-perceived» parts of the -ing) (Duffley 1995: 4); hence, the observer or experiencer regards the situation as an ongoing state of affairs:

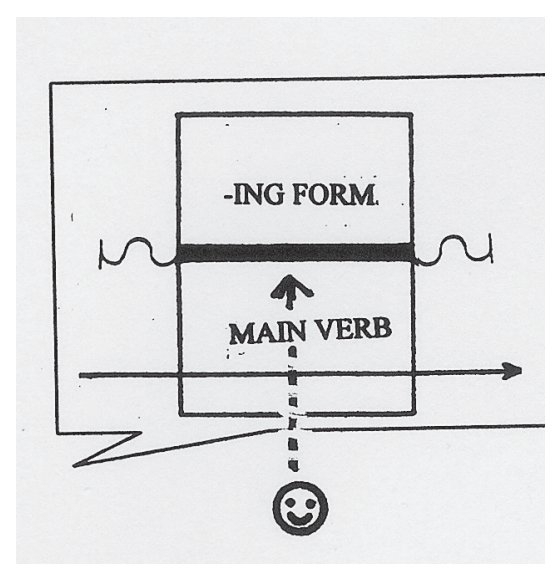

Figure (4): The «participial interpretation» of the -ing form

As far as the the «gerundial interpretation» is concerned, firstly the main clause subject has a certain responsibility in relation to the content evoked by the complement clause. In fact, he/she can make a decision to suspend the event complement by stopping the image, the remembrance, or the physical perception of it (this is represented by a vertical arrow). And, secondly, the observer or experiencer conceptualizes the internal

3 These observations have also been presented in our article entitled «Syntactic and Semantic Interaction in English Gerund-Participle» published in International Journal Studies, vol. 7 (1), 2007, 35-45. 
configuration of the complement event; in other words, he/she construes the event as a whole (this is represented by a bold straight line) (Duffley, 1995: 5):

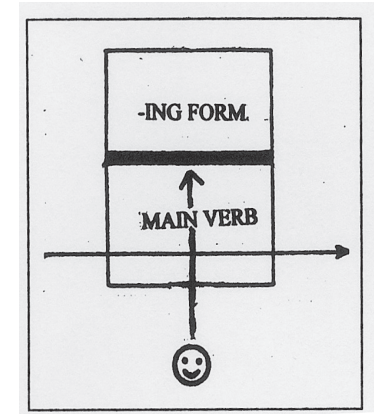

Figure (5): The «gerundial interpretation» of the -ing form

We could end up stating that sentences such as I see my father diving into the sea can have both a participial and gerundial interpretation. The participial interpretation implies that the speaker places the emphasis only on part of the diving process and in this sense, the complement clause subject is responsible for the process (i.e. my father). The gerundial interpretation, however, conveys the idea that the speaker conceptualizes the diving process as a whole, in which the main clause subject (i.e. I) is fully involved.

For the sake of our study we will focus on the gerundial interpretation. The -ing form with a gerundial interpretation can also be expressed in terms of the «conceptual subordination process» according to the terminology of Langacker (1991:440; 2008: 412-419). According to this author, when the -ing constructions function as complements, they undergo a conceptual subordination process. This means that these constructions play a role as a participant of the main clause, which implies, in turn, that they do not represent a canonical construction, but that they are holistically conceptualized and interpreted as a single entity.

At this point, we think it is necessary to justify the inclusion of the sequence [physical perception verb $+\mathrm{NP}+$ English gerund] again, but from a different perspective. Firstly, on the assumption that the-ing form with physical perception verbs has two possibilities, a «participial reading» and a «gerundial reading», the «gerundial reading» provides a complementary dimension of the -ing form in relation to previous perception literature. Moreover, this reading helps us understand the complexity of the -ing form from a non-discrete approach: this category must be interpreted as a continuum with different readings.

\section{ANALYSIS AND DISCUSSION OF DATA: CONTRASTIVE AND COGNITIVE STUDY}

Now that we have presented the characterization of the English gerund and its status combined with physical perception verbs, we will proceed to analyze the conceptualization of the Spanish equivalents with regard to the English gerund. From our corpus data, 
we have corroborated that the syntactic expressions of the Spanish equivalents (i.e. the percept) combined with physical perception verbs are the following: i) non-finite verbs: the infinitive (46\%), the gerund (22\%) and the participle (5\%); ii) complement clauses with «that»: That-clause (10\%) and relative clause (5\%); and iii) a substantive or a noun phrase (NP) $(12 \%)^{4}$ (Rodríguez Espiñeira, 2000: 46). Although there is some disparity between the equivalents in terms of frequency (i.e. the infinitive and the substantive are the first and second most frequent equivalents, while the rest represent minority cases), all these syntactic expressions have two points in common: firstly, they represent different degrees of equivalence and, secondly, they reflect, in general, different ways of exploiting the eventive reading of the English gerund, as argued in the following sections.

\subsection{Non-finite verbs}

With regard to non-finite verbs, we claim that the Spanish infinitive, gerund and participle have an important point in common with the English gerund: they share a summary scanning. However, the Spanish equivalents basically differ from the English gerund in their «aspectual dimension» (Albalá, 1988; Fernández Lagunilla, 1999; López García, 2005). In fact, this «aspectual dimension» is responsible for the different conceptualization of each Spanish equivalent in relation to the English gerund.

Regarding the Spanish infinitive, this category when combined with physical perception verbs (such as «see», «observe», etc.) has an eventive reading according to Hernanz (1999: 2242); that is to say, the infinitives must be interpreted as actions or processes confined in space and time in these constructions.

In relation to the aspectual dimension, the Spanish infinitive reflects the neutral member and represents an event without contemplating the possibility of its ending according to Albalá's classification (1988: 14). To rephrase it, the infinitive provides a scene without an end. This is directly related to the cognitive characterization of the English gerund (3.1.). Moreover, these two categories (i.e. English gerund and the Spanish infinitive) can be construed as an event seen as a whole without an internal temporal structure (i.e. no beginning, middle and end) (Albalá, 1988; Hernanz, 1999; Declerck, 2006).

Nevertheless, we corroborate that the infinitive with physical perception verbs can describe states of affairs with a different eventive structure (i.e. atelic and telic events), which is also the case for the English gerund. In these cases we consider that the construction and the context are responsible for imposing a synoptic or conclusive interpretation according to Hanegreefs's terminology (2008: 82). A synoptic or conclusive interpretation is related to the definition of telicity. The concept of (a)telicity refers to whether or not a situation is described as having an inherent or intended endpoint:

(2) a. Julia, que estaba mirando por la ventana, la vio llegar. Al menos aquel abrigo elegante constituía una mejora con respecto a la gruesa trenca de lana. (SUEDUL 904)

4 We provide the relative frequency of the Spanish equivalents because our study is methodologically corpus-based but it is important to signal out that our approach is mainly qualitative. 
b. Julia was standing at her high window, looking down, when she saw Frances approaching. At least this smart coat was an improvement, not the usual duffelcoat. (SWEE 904)

In (2a), «llegar» ('approaching') is limited by the temporal limits of «vio» ('saw') in the past tense. Furthermore, the presence of contextual clues (e.g. «aquel abrigo elegante» ('this smart coat') imposes limits to the event denoted by «llegar».

In some contexts, the Spanish infinitive and English gerund can appear with their subject. In these cases, they differ in the role their subjects play in these constructions. In Spanish, the agentive role of the infinitive's subject has a higher predominance than in English (Hanegreefs, 2008: 93), as far as agentivity is concerned. In (2) the subject's preposing position in relation to the physical perception verb, (i.e. la vio llegar), is conditioned by «its degree» of agentivity (Delbecque, 1987; 2005); that is to say, the closer the subject is to a prototypical agent, the less likely it may appear postponed (Hanegreefs, 2008: 87). Furthermore, this «subject's preposing position» is an indication of the strong bond and interdependence between the physical perception verbs and the Spanish infinitive. In short, we argue that the Spanish infinitive with an explicit subject reflects a higher degree of cohesion with physical perception verbs than the English gerund. Moreover, both categories, the Spanish infinitive and the English gerund (to a lower degree), represent a conceptual continuity with regard to physical perception verbs and together with their subjects they reflect a single event (Verhaert, 2006: 339).

With regard to the Spanish gerund, the construction of a gerund with physical perception verbs preceded by its notional subject is quite predictable in Spanish. These constructions have been denominated as «predicate gerunds» ('gerundios predicativos') according to Fernández Lagunilla (1999: 3489). Semantically, predicative gerunds are verbal predicates and as such they denote actions, processes or states of individuals (Fernández Lagunilla, 1999: 3461). Predicate gerunds with physical perception verbs are characterized by the possibility of elaborating the eventive base of a percept. In this regard, the Spanish gerund reflects a scene in media res of the event referred to by the complement clause (Albalá, 1988: 14), or, in other words, the Spanish gerund («haciendo») represents a single episode, or a portion of the activity, in which the notional subject of the gerund («tus padres») participates (Langacker, 2008; Hanegreefs, 2008), as shown in the following example:

(3) a. Si sorprendiste a tus padres haciendo el amor. (TERA 791)

b. You saw your parents having it off together. (THE 791)

In this regard, we advocate that the Spanish predicative gerund and the English gerund differ in the way they conceptualize the event they denote: while the Spanish gerund provides a portion or phase of the event (Fernandez Lagunilla,1999: 3456; Albalá, 1988: 15-16; López García, 2005: 167; Izquierdo Fernandez, 2008: 96); the English gerund evokes the event conceptualized as a whole (e.g. «your parents having it off together») in (3b).

In a similar way to the Spanish gerund, the Spanish participle can express an eventive reading or, in other words, it can elaborate the eventive interpretation of a percept. According to Bosque (1999: 277), although participles show similar behaviour to adjec- 
tives (e.g. they have gender and number, and also are predicates of nominal entities), the participle expresses grammatical behaviour of a verbal nature. And it is precisely this verbal character that makes it possible to evoke an action or a process conceptualized as a result (i.e. the final state of a process or event). In terms of the aspectual dimension, according to Albalá's classification (1988: 14), the participle presents the scene with its ending. This aspectual dimension reflects a difference in the conceptualization of the participle with respect to that of the English gerund. In particular, we observe that the Spanish participle combined with physical perception verbs tends to favour a physical description of the percept:

(4) a. Ya eran las nueve; muy tarde para Frances. Tenía que levantarse. Abrió la puerta del pasillo y vio a Andrew sentado en el suelo. (SUEDUL 930)

b. It was nine o'clock by now, late for her. She must get up. She opened the door on to the landing and saw Andrew sitting on the floor. (SWEE 54: 930)

\subsection{Complement clauses with «that»}

Unlike non-finite verbs, complement clauses with «that» (i.e. That-clause and relative clause) provide a quite different conceptualization in relation to the English gerund. They differ from the English gerund in three significant ways. Firstly, these complement clauses, unlike the English gerund, have a sequential scanning, or in other words, the states are described individually. Secondly, they have their own grounding (Langacker, 2008: 354). And, finally, they behave like independent clauses. However, these complement clauses with «that» differ in their degree of independent clause behaviour, which is greater in the case of the that-clause and lower for the relative clause, as argued in the following paragraphs.

The that-clause shows a greater syntactic and semantic autonomy compared to nonfinite verbs and the relative clause. This independent clause behaviour can be explained by the presence of the complementizer «that» which marks the transition between main and complement clause on a syntactic level, and also by the absence of a NP preceding the complement clause, which would act as a pivot between the main and complement clauses, as in the case of the relative clause. From a conceptual point of view, these two elements (i.e. presence of «that» and the absence of a NP) create a great conceptual distance between the participants (i.e. main and complement clauses) (Hanegreefs, 2008:121). The conceptual distance is related to the complexity concept in terms of Rohdenburg (1995: 368). According to this author, the degree of complexity of a complement clause is reflected by the presence of complements and adjuncts between the complement and main clause. A low level of cohesion between the that-clause with the main clause is shown by the presence of the complementizer «that». Indeed, due to its autonomous character, the that-clause puts its own participants on a stage and, therefore, the whole construction evokes two different scenes (represented by two different underlined parts):

(5) a. ¿Desde cuándo? Veo que estás sufriendo, Drenka. No quiero que sufras, pero no puedo tomarme en serio lo que me pides. (TEASAB 149)

b. «Since when? Drenka, I see you suffering, I don't want you to suffer, but I cannot take seriously what you are asking of me. (SAB 149) 
Based on the data of our corpus, we corroborate that the that-clause combined with physical perception verbs stages an event that, in general, can be directly perceived (i.e. physically perceptible) by the senses, but it can also be inferred by other means (e.g. intellectually perceptible) (Hernandez, 1999: 2241). The suffering of a person in (5) may be manifest on a physical level, but it can also be attested by a change in habits or behaviour of the person concerned (e.g. lack of vitality, activity, physical condition, etc.).

All these factors confirm, in our view, that the that-clause should be understood as a process of decentralization with respect to the conceptualization of English gerund constructions. By the term decentralization, we mean the opposite trend we observe in the English constructions with the English gerund. English tends to organize the construction with the English gerund focused on the main subject, that is, the active participant, (S1). This agentive entity is either full or has a certain responsibility for the event denoted by the complement clause (represented by an arrow) as shown in the figure below:

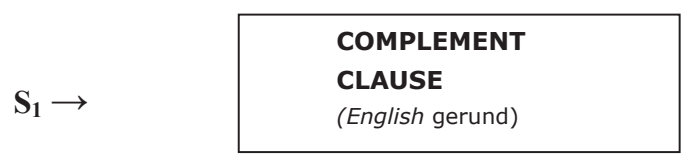

Figure (6): The centralization of English gerund conceptualization

In contrast, the that-clause «decentralizes» the English model and includes the subject of the Noun Phrase in the English version as the subject of the complement clause (S2). The Spanish That-clause provides two scenarios with two agentive entities or subjects: the main subject, $\mathrm{S} 1$, is not directly responsible for the complement clause (indicated by an arrow with chopped strokes) and it is precisely the second active participant, $\mathrm{S} 2$, that is directly responsible for the second scenario which is reflected by an arrow:

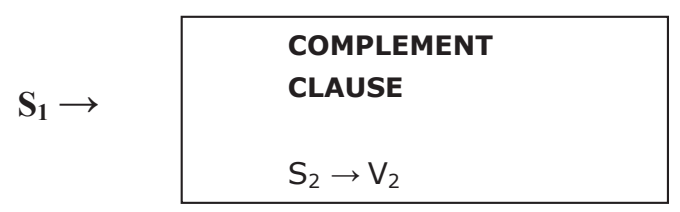

Figure (7): The decentralization of that-clause in relation to the English gerund

With regard to the relative clause, as noted earlier, it shows behavior similar to that of the that-clause. The relative clause is also characterized by a sequential scanning, its own grounding and independent clause behaviour. However, the relative clause shows less autonomy than the that-clause due to the presence of a NP (i.e. antecedent/percept). This NP precedes the complement clause and acts as a pivot between the main clause and the relative clause. According to Brucart (1999: 397), the relative clause is not directly integrated into the main clause, due to its role as a modifier. On the other hand, the Spanish relative clause differs from the English gerund 
in the interpretation of the role of the NP (Verhaert, 2006: 330): the relative clause is structured around the NP whereas the English gerund integrates it into its own construction.

In particular, the relative clause with physical perception verbs inscribes the event it denotes into the same time frame of the main clause and this implies that the relative clause must be interpreted as a coextension of the main clause event (Hanegreefs, 2008: 104). To put it another way, the relative clause with physical perception verbs denotes a «continuous, uninterrupted image of the event» (Hanegreefs, 2008:106), as seen in (6):

(6) a. Los pocos detalles de la película que habían perdurado en mi memoria eran ${ }^{2} \operatorname{los}$ efectos especiales cuando morían los personajes: por ejemplo, el héroe se levanta del suelo, aparentemente ileso, y sólo se percata de que está muerto cuando ve a su novia consternada que acuna en sus brazos su cuerpo sin vida. (PENSA 752) b. The few details of the movie that had lodged in my memory were the special effects when characters died: for instance, the hero gets up from the ground apparently unscathed and only realizes that he's dead when he sees his distraught girlfriend cradling his own lifeless body in her arms. (THIN 752)

\subsection{Substantives}

In order to provide a complete overview of the Spanish equivalents combined with physical perception verbs, we will cover the substantive. The number of examples illustrating the equivalence between the substantive and the English gerund shows that there is a cognitive parallelism between them. In short, it can be asserted that both categories (i.e. the English gerund and the Spanish substantive) express a profiled region lacking inherent bounding within the scope of predication, since the endpoints of the process fall outside the relevant predication (Langacker, 2008: 121, 155). However, the substantive and the English gerund differ in one key aspect: the Spanish substantive displays different conceptualization levels. It can evoke an object, an event, a proposition and a metalinguistic object according to Delbecque \& Lamiroy (1999). In fact, with physical perception verbs, the Spanish substantive can be of a concrete nature (i.e. object), as in «chorro del agua» ('water gushing') in (7), or abstract (i.e. proposition), like «gélidas críticas» ('shrilly criticizing') in (8). The variety of substantives functioning as percepts of physical perception verbs corroborates that substantives reflect different levels of conceptualization:

(7) a. Ella oyó el chorro del agua un buen rato. Oyó el chapoteo del agua contra los costados de la bañera mientras él se movía. (ENCUEN 575)

b. She heard the water gushing a long time. She heard it slapping against the sides of the tub as he moved about within. (PICK 575)

(8) a. He had already been heard shrilly criticizing her for lack of chic. 'Being a freak isn't smart, love,' he had said. To which she had replied, 'And who's talking?' (LOVE 999)

b. Ya se le habían oído gélidas críticas hacia ella por falta de chic.

- Ser un monstruo no es elegante, cariño -le había dicho. A lo que ella había contestado:

- Mira quién habla. (AMOR 999) 
From the above observations we can draw the following generalizations regarding the different levels of conceptualization of the Spanish equivalents. Concerning non-finite verbs, the infinitive expresses a scene without an end; the gerund is an image taken at any time of the event in its development, and, finally, the participle shows a scene with its end in order to physically describe a percept. In relation to complement clauses with «that», the that-clause represents two scenes or windows, whereas the relative clause denotes a continuous or uninterrupted image. Finally, substantives can evoke entities of both a concrete and an abstract nature.

On the whole, based on our corpus data, the situation that emerges is that, in general, the Spanish equivalents are inclined to exploit the eventive reading of the English gerund but they do it from a different perspective:

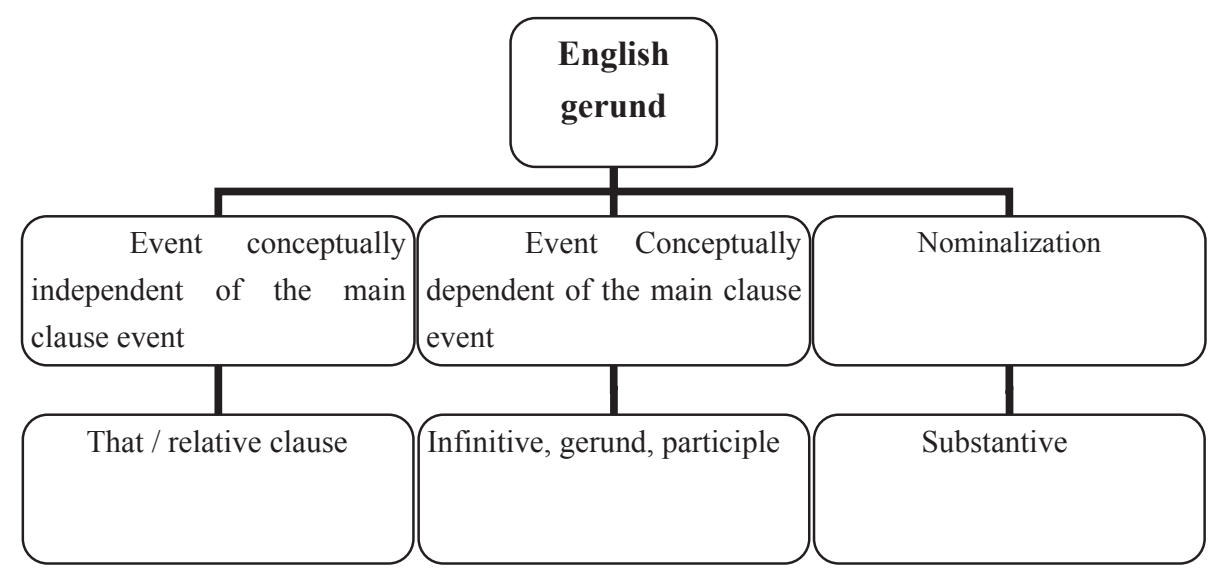

Figure (8): The Spanish equivalents of the English gerund according to their eventive reading

The differences in the way the equivalents update the eventive reading are detailed in the following lines. The that-clause presents an event conceptually independent from the main clause due to its syntactic and semantic autonomy. The relative clause is somewhere between the that-clause and the non-finite verbs. On the one hand, the relative clause coincides with the that-clause in implying a great conceptual distance between the main and complement clauses, but, on the other hand, it shares its complementary character with the non-finite verbs. Unlike the that-clause and the relative clause, non-finite verbs (i.e. infinitive, gerund and participle) evoke an event conceptually dependent, to a greater or lesser extent, on the main clause event. Finally, the substantive denotes a nominalization process; however, it is possible, in general, to infer the presence of an agentive entity.

\section{Conclusions}

In conclusion, we have been able to determine the different levels of conceptualization between the English gerund and its Spanish equivalents. In this regard, the cognitive 
approach analysis proves to be a suitable approach for this paper. In fact, this approach provides a valid characterization of the English gerund which constitutes, in turn, the base for the contrastive cognitive study.

With regard to the status of the -ing form, we have corroborated that the -ing form can be interpreted as a gerund or a participle in some special cases. In particular, we have proven that the -ing form in the sequence [physical perception verb $+\mathrm{NP}+$ the -ing form] has an extra possibility: a gerundial reading. This gerundial reading justifies the inclusion of this construction in this paper. Moreover, we think that this gerundial reading provides a complementary dimension in relation to previous studies in perception.

Finally, as far as the Spanish equivalents are concerned, we have confirmed, on the one hand, that all the equivalents reflect different levels of conceptualization in relation to the English gerund and, on the other hand, that the Spanish equivalents update the eventive reading of the English gerund in a different way.

\section{REFERENCES}

Albalá, M. J. (1988). Contribución al estudio del gerundio en la lengua español hablada de Madrid. Doctoral Dissertation, University of Madrid, Spain.

Bosque, I. (1999). El adjetivo: clases y usos. La posición del adjetivo en el sintagma nominal. In I. Bosque \& V. Demonte (Eds.), Gramática descriptiva de la lengua española, (Vol. 1), (pp.129-217). Madrid: Espasa Calpe.

BruCART, J. M. (1999). La estructura del sintagma nominal: la oración de relativo. In I. Bosque \& V. Demonte (Eds.), Gramática descriptiva de la lengua española, (Vol. 1), (pp. 363-395). Madrid: Espasa Calpe.

Croft, W. (1993). Case marking and the semantics of mental verbs. In J. Pustejovsky (Ed), Semantics and the Lexicon (pp. 55-72). Netherlands: Kluwer Academic Publishers.

Declerck, R. (2006). The Grammar of the English Verb Phrase. (Vol. 1). Berlin/New York: Mouton de Gruyter.

Delbecque, N. (1987). Problèmes et méthodes de l'étude de la variation syntaxique: le cas de la position du sujet en espagnol. Leuven: Universitaire Pers.

Delbecque, N. \& Lamiroy, B. (1999). La subordinación sustantiva: las subordinadas enunciativas en los complementos verbales. In I. Bosque \& V. Demonte, (Eds.), Gramática descriptiva de la lengua española, (Vol. II), (pp.1931-1965). Madrid: Espasa Calpe.

Duffley P. J. (1995). Defining the Potential Meaning of the English -ing Form in a Psychomechanical Approach. Langues et Linguistique 21, 1-11.

- (2006): The English Gerund-Participle, A Comparison with the infinitive. Berkeley Insights in Linguistics and Semiotics (Vol. 61). New York: Peter Lang.

Fernández Lagunilla, (1999). Las Construcciones de Gerundio. In I. Bosque \& V. Demonte, (Eds.), Gramática descriptiva de la lengua española (Vol. III) (pp. 3391-3443): Madrid: Espasa Calpe.

Givón, T. (1993). English Grammar. A function-based introduction (Vol. 2). Amsterdam/Philadelphia: John Benjamins.

Hamawand, Z. (2002). Atemporal Complement Clauses in English: A cognitive Grammar Analysis. Muenchen: Lincom Europa.

HANEGReEfs, H. (2008). Los verbos de percepción visual. Un análisis de corpus en un marco cognitivo. Doctoral Dissertation, Katholieke Universiteit leuven, Belgium.

Hernanz, L. (1999). El infinitivo. In I. Bosque \& V. Demonte, (Eds.), Gramática descriptiva de la lengua española (Vol. II) (pp. 2196-2356). Madrid: Espasa Calpe. 
IZQUIERDO, M. (2008). Estudio contrastivo y de traducción de las construcciones de -ing inglesas $y$ sus equivalentes en español. Doctoral Dissertation, University of Leon, Spain.

Johansson. (1998). On the role of corpora in cross-linguistics research: In S. Johansson \& S. Oksefjell (Eds.), Corpora and Cross Linguistics Research (pp. 3-24). Amsterdam: Rodopi.

LANGacker, R. W. (1991). Foundations of Cognitive Grammar (Vol. 2). Standford: Standford University Press.

- (2000). Grammar and Conceptualization. Berlin / New York: Mouton de Gruyter.

- (2008). Cognitive grammar: a basic introduction. Oxford: Oxford University Press.

López García, Á. (2005). Gramática cognitiva para profesores de español L2. Madrid: Arco Libros

Mauranen, A. (2002). Will 'translationese' ruin a contrastive study? Languages in contrast 2 (2), 161-185. Amsterdam-Philadelphia: John Benjamins.

Rodríguez EsPiÑEIRA, M.J. (2000). Percepción directa e indirecta en español: Diferencias semánticas y formales. Verba: Anuario Galego de filoloxia, 27, 33-85.

Teubert, W. (2005). My Version of Corpus Linguistics. International Journal of Corpus Linguistcs, 10 (1), 1-13.

VERHAERT, A. (2006). El gerundio no perifrástico del español y sus equivalentes en neerlandés: una aproximación cognoscitivo-funcional. Doctoral Dissertation, Katholieke Universiteit leuven, Belgium.

Verspoor, M. (1996). The story of -ing: A subjective perspective. In M. Pütz \& R. Dirven (Eds), The construal of Space in Language and Thought (pp. 417-454).

WierzBicka, A. (1988). The Semantics of Grammar. Amsterdam - Philadelphia: John Benjamins. 